\title{
Pengaruh Latihan Plyometric Double Leg Speed Hop dan Single Leg Bounding Terhadap Kecepatan Tendangan Sabit Pada Atlet Putra Perguruan Pencak Silat Al-Hikmah Ar-Rahiim Kabupaten Deli Serdang
}

\author{
Rizka Hayati, Dewi Endriani \\ Fakultas Ilmu Keolahragaan, Universitas Negeri Medan \\ rizkahayati58@gmail.com,dewiendriani80@gmail.com
}

\begin{abstract}
Abstrak: Tujuan penelitian yang ingin dicapai dalam penelitian ini adalah untuk mengetahui pengaruh latihan plyometric double leg speed hop dan single leg bounding terhadap kecepatan tendangan sabit pada atlet putra perguruan al-hikmah ar-rahiim kabupaten deli serdang tahun 2021. Metode penelitian yang digunakan adalah quasi eksperimen. Sampel yang digunakan dalam penelitian ini adalah atlet perguruan al-hikmah ar-rahiim sebanyak 10 orang. Dari analisis hasil data yang telah dilakukan dapat disimpulkan terdapat pengaruh yang signifikan bahwa melalui latihan plyometric double leg speed hop dan single leg bounding dapat meningkatkan kecepatan tendangan sabit pada atlet putra perguruan pencak silat al-hikmah ar-rahiim kabupaten deli serdang, dengan analisis hipotesis dari data pre-test dan post-test hasil kecepatan tendangan sabit diperoleh $t_{\text {hitung }}$ sebesar $=7,05$ serta dengan nilai $t_{\text {tabel }}$ sebesar $=1,83$ dengan $\alpha=0,05$ ( $\left.\mathrm{t}_{\text {hitung }}>\mathrm{t}_{\text {tabel }}\right)$ atau $(7,05>1,83)$. Hal ini berarti $\mathrm{H}_{0}$ ditolak $\mathrm{H}_{a}$ diterima.
\end{abstract}

Kata Kunci : Plyometric, Tendangan Sabit, Pencak Silat

\section{The Effect of Plyometric Exercises Double Leg Speed Hop and Single Leg Bounding on the Speed of Sabit Kicks in Male Athletes of Al-Hikmah Ar-Rahiim Pencak Silat College Deli Serdang Regency}

\begin{abstract}
The research objective to be achieved in this study is to determine the effect of plyometric double leg speed hop and single-leg bounding exercises on the speed of the sabit kick in the male athletes of al-hikmah ar-rahiim college, deli serdang regency in 2021. The research method used is quasi experiment. The sample used in this study was 10 athletes from the al-hikmah ar-rahiim college. The analysis of the data results that have been carried out, it can be concluded that there is a significant effect that through plyometric exercise double leg speed hop and single leg bounding can increase the speed of the sabit kick in the male athlete of the al-hikmah ar-rahiim pencak silat college, deli serdang regency, with analysis The hypothesis from the pre-test and post-test data obtained that the speed of the sickle kick was $=7.05$ and with a value of $=1.83$ with $\alpha=0,05$ ( thitrong $>$ twathal $)$ or $(7,05>1,83)$. This means that it is rejected.
\end{abstract}

Keywords: Plyometric, Sabit Kicks, Pencak Silat

\section{PENDAHULUAN}

Pencak silat merupakan salah satu budaya asli bangsa Indonesia, dimana sangat diyakini oleh pendekarnya dan para pakar pencak silat bahwa masyarakat melayu saat itu menciptakan dan mempergunakan ilmu bela diri ini sejak di masa pra sejarah. Pencak silat merupakan cara membela diri yang sesuai dengan alam sekitarnya dan telah berkembang sejak zaman penjajahan. Menurut Lubis (2004: 7) Gerak dasar pencak silat adalah suatu gerak gerak terencana, terarah, terkoordinasi dan terkendali, yang mempunyai empat aspek sebagai satu kesatuan, yaitu aspek mental spiritual, aspek bela diri, aspek olahraga, dan aspek seni budaya. Dengan demikian, pencak silat merupakan satu 
kesatuan utuh dan tidak bisa dipisah-pisah.

Teknik dasar dalam pencak silat salah satunya adalah tendangan. Tendangan dalam pencak silat ada beberapa macam yaitu tendangan lurus, tendangan $\mathrm{T}$ dan tendangan sabit. Diantara tendangan yang paling sering digunakan adalah tendangan sabit, dimana tendangan sabit dapat mengeluarkan suara yang kuat saat menendang. Tendangan sabit merupakan Serangan dengan tendangan yang memiliki power dan dilakukan dengan cepat. Untuk melakukan serangan tendangan sabit diperlukan jarak yang pas, karena jangkauan pada tendangan ini harus lebih dekat dibandingkan dengan tendangan lain. Oleh sebab itu tendangan sabit merupakan tendangan yang sangat mudah ditanggap oleh lawan, sehingga memerlukan kecepatan dalam melakukan tendangan ini. Selain itu, pada tendangan sabit jarak dengan lawan harus seimbang, lebih kuat dan cepat karena tendangan ini menggunakan punggung sebagai alat serang, pesilat dapat mengeksplorasi tenaga dengan lebih maksimal. Sebagaimana dikatakan Lubis dan Wardoyo (2014: 38) tendangan sabit adalah tendangan yang lintasannya setengah lingkaran ke dalam, dengan sasaran seluruh bagian tubuh, dengan punggung telapak kaki atau jari telapak kaki. Oleh sebab itu diperlukannya tendangan yang menggunakan kecepatan dalam melakukan serangan dengan menggunakan tendangan sabit agar tidak mudah ditangkap oleh lawan.

Sebuah serangan tendangan diperlukan kondisi fisik, salah satunya adalah latihan kecepatan. Untuk meningkatkan kecepatan diperlukan latihan yang tepat dengan unsur-unsur yang menentukan kecepatan tendangan sabit dengan harus memperhatikan kondisi fisik yang mendukung kecepatan tendangan sabit. Selaras dengan itu, disini peneliti melakukan observasi di Perguruan Pencak Silat AlHikmah Ar-Rahiim Kabupaten Deli Serdang.

Dari hasil observasi kecepatan tendangan dari atlet Putra Perguruan Pencak Silat Al-hikmah masih sangat kurang dikarenakan beberapa faktor yang menghambat atlet. Hal ini diperkuat lagi dengan wawancara dengan pelatih bahwasannya dalam pencak silat tendangan merupakan salah satu teknik yang harus di kuasai oleh atlet pencak silat dan dalam melakukan tendangan yang baik haruslah dilakukan dengan cepat, kuat, tepat dan akurat. Tetapi atlet belum mencapai hal tersebut. Permasalahan atlet adalah kecepatan tendangan sabit, dimana tendangan dari atlet tersebut masih sangat lambat dikarenakan kurangnya program latihan yang terprogram selama ini dan masih singkatnya masa latihan mereka menyebabkan atlet lambat untuk berkembang.

Permasalahan tersebut ditimbulkan karena kurangnya program-program latihan dari pelatih untuk meningkatkan tendangan sabit yang mengakibatkan kurang baiknya kecepatan tendangan atlet. Dengan demikian disini peneliti memberikan solusi yang tepat dan sesuai dengan kondisi yang ada. Untuk mendapatkan tendangan sabit yang cepat, kuat dan akurat kearah sasaran maka para atlet akan diberikan latihan kondisi fisik yang merupakan salah satu syarat penting.

Untuk melatih kecepatan tendangan sabit dapat dilakukan latihan pengembangan kecepatan kaki. Menurut Kurniawan \& Mylsidayu (2015) menyatakan bahwa, speed merupakan salah satu komponen dasar biomotor yang sangat penting dalam setiap cabang olahraga. Setiap aktivitas olahraga yang bersifat permainan, perlombaan, maupun pertandingan selalu memerlukan komponen-komponen speed. Begitu juga kecepatan tendangan dalam pencak silat dapat dicapai melalui latihan secara terpogram dan intensif.

Menurut Radcliffe dan Farentinos (Siswanto,2014), latihan plyometric telah digunakan sebagai metode latihan tertama untuk mengembangkan kekuatan, kecepatan dan power. Latihan plyometric mengembangkan otot dengan hentakan balik yang dikenal dengan istilah "stretch/reflex" yang dilakukan pada suatu kelompok otot, yang merupakan kunci dan cara yang paling baik untuk melatih otot selain kekuatan juga kecepatan. Sebagaimana dikatakan oleh Shepherd (2009: 13) latihan plyometric juga dapat mengembangkan elastisitas otot dengan cara melatih regangan-regangan otot untuk kemudian berekasi untuk melakukan gerakan tertentu. Karyono (2016: 52), latihan plyometric, seseorang dapat meningkatkan kesegaran biomotorik, kekuatan, kecepatan, dan power.

Senada dengan pendapat diatas, Davaran et, al (2014) mengatakan bahwa pelatihan plyometric pada kekuatan otot memberikan fungsi yang lebih tinggi setelah melakukan latihan. Menurut Chu dan Mayer (2013:83) latihan plyometric adalah sebuah program latihan yang digunakan untuk mengembangkan kekuatan dan kecepatan untuk pesilat. Latihan plyometric yang akan digunakan dalam penelitian ini adalah Plyometric Double Leg Speed Hop dan Single Leg Bounding. Peneliti merasa perlu adanya latihan fisik untuk meningkatkan kecepatan, namun untuk usia pra remaja seperti yang peneliti akan lakukan penelitian akan didiberikan porsi latihan yang sesuai. 
Double Leg Speed Hop adalah pelatihan yang dilakukan dengan cara posisi badan berdiri dengan setengah jongkok, kedua kaki diregangkan selebar bahu, kemudian meloncat ke atas depan dengan cepat hingga posisi kaki di bawah bokong dan selanjutnya mendarat dengan kedua kaki (Furqon dan Doewes: 2002). Pelatihan Double Leg Speed Hop tersebut merupakan bentuk latihan meloncat memantul yang sangat efektif untuk meningkatkan power otot tungkai.

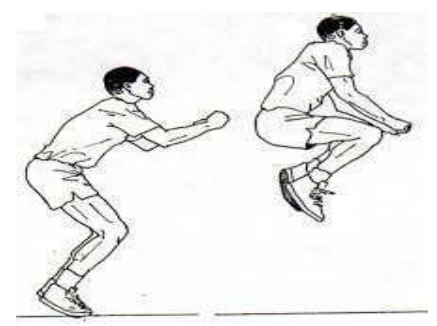

Gambar 1. Double Leg Speed Hop (Chu \& Mayer, 2013)

Single leg bounding adalah gerakan meloncat kedepan dengan loncatan setinggi dan sejauh mungkin. Latihan ini merupakan salah satu bentuk latihan plyometric yang sangat baik untuk meningkatkan kemampuan kondisi fisik. Tujuan dari latihan Single Leg Bounding adalah untuk meningkatkan kekuatan reaktif seorang pesilat, semakin sedikit lentur dari lutut dan semakin sedikit waktu kaki berada dalam kontak dengan tanah, maka akan lebih efektif. Tujuan dari latihan single leg bounding adalah untuk meningkatkan kekuatan reaktif seorang pesilat, semakin sedikit lentur dari lutut dan semakin sedikit waktu kaki berada dalam kontak dengan tanah, maka akan lebih efektif.

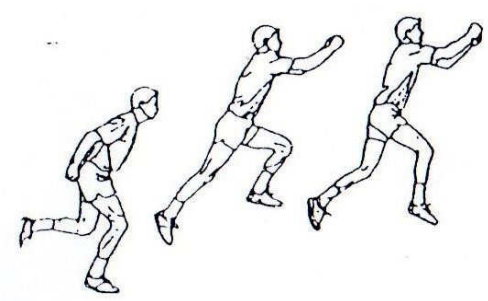

Gambar 2. Single leg bounding (Chu \& Mayer, 2013)

\section{METODE}

Metode penelitian yang digunakan dalam penelitian ini adalah penelitian eksperimen yaitu quasi eksperimen melalui pengumpulan data dengan menggunakan tes dan pengukuran. Penelitian ini mencoba untuk mengetahui pengaruh latihan plyometric double leg speed hop dan single leg bounding sebagai variabel bebas terhadap kecepatan tendangan sabit sebagai variabel terikat. Peneliti akan menemukan informasi tentang pengaruh latihan plyometric double leg speed hop dan single leg bounding terhadap kecepatan tendangan sabit Atlet putra di perguruan pencak silat al-hikmah arrahiim kabupaten deli serdang.

Karena data dalam penelitian ini berupa angka-angka (kuantitatif), maka perlu diambil langkahlangkah dalam menganalisis data dalam penelitian ini adalah menggunakan uji t. (Sudjana, 2009). Pada dasarnya seorang peneliti harus mengetahui jenis data apa yang harus digunakan. Dengan demikian peneliti akan memperoleh hasil yang relevan terhadap objek yang ditelitinya sehingga dapat dipercaya.

Instrumen pengukuran dalam penelitian ini menggunakan tes kecepatan tendangan sabit dengan banyaknya tendangan yang dapat dilakukan dalam waktu 10 detik dan akan dilihat hasil tendangan sesuai dengan standart penilaian tendangan sabit. Waktu penelitian dilaksanakan selama enam minggu dengan frekuensi latihan dilaksanakan tiga kali pertemuan dalam seminggu dimana latihan dilakukan pada pagi dan sore hari di gelanggang perguruan. 
Populasi dalam penelitian ini adalah seluruh pesilat di Perguruan Pencak Silat Al-Hikmah ArRahiim Kabupaten Deli Serdang, yang berjumlah 30 orang. Teknik pengambilan sampel yang digunakan dalam penelitian ini adalah teknik purposive sampling yang menghasilkan 10 atlet putra. Desain penelitian yang peneliti gunakan adalah desain penelitian eksperimen dalam bentuk one group pre test - post test design.

Metode penelitian yang digunakan dalam penelitian ini adalah penelitian eksperimen yaitu quasi eksperimen melalui pengumpulan data dengan menggunakan tes dan pengukuran.Dalam penelitian ini, peneliti mencoba untuk meneliti pengaruh latihan plyometric double leg speed hop dan single leg bounding sebagai variabel bebas terhadap kecepatan tendangan sabit sebagai variabel terikat. Peneliti akan menemukan informasi tentang pengaruh latihan plyometric double leg speed hop dan single leg bounding terhadap kecepatan tendangan sabit Atlet putra di perguruan pencak silat al-hikmah arrahiim kabupaten deli serdang. Metode ini memiliki pengertian bahwa peneliti memberikan perlakuan tertentu kepada subjek untuk melihat apakah ada pengaruh dari perlakuan tersebut.

\section{HASIL DAN PEMBAHASAN}

Adapun hasil dari deskripsi data penelitian yang dilakukan melalui tes pengukuran terhadap kemampuan Kecepatan Tendangan sabit adalah sebagai berikut.

Tabel 1. Deskripsi Data Pre-Test Dan Post-Test Hasil Kecepatan Tendangan Sabit

\begin{tabular}{c|c|c}
\hline \multirow{2}{*}{ Deskripsi Data } & \multicolumn{2}{c}{ Data Hasil Kecepatan Tendangan Sabit } \\
\cline { 2 - 3 } & Pre-test & Post-test \\
\hline Nilai rata-rata & 17,7 & 23,9 \\
\hline Simpangan baku & 1,56 & 2,51 \\
\hline Rata-Rata Beda & \multicolumn{2}{|c}{6,2} \\
\hline Simpangan baku beda & 2,78 \\
\hline t-hitung & \multicolumn{3}{|}{7,05} \\
\hline t-tabel & \multicolumn{3}{|c}{1,833} \\
\hline
\end{tabular}

Dari hasil pre-test hasil tendangan sabit diperoleh nilai rata-rata 17,7 dan simpangan baku 1,56. Dari hasil post-test diperoleh rata-rata 23,9 dan simpangan baku 2,51. Dari rata-rata pre-test dan posttest didapat nilai rata-rata beda 6,2 dengan simpangan baku beda 2,78 sehingga didapat $t_{\text {hitung }} 7,05$ dan $\mathrm{t}_{\text {tabel }} 1,83$.

Pengujian Normalitas Data dengan menggunakan Uji Lilifors, dari kolom daftar pre-test kelompok latihan Plyometric Double Leg Speed Hop dan Single Leg Bounding terhadap Kecepatan Tendangan Sabit Pada Atlet Putra Perguruan Pencak Silat Al-Hikmah Ar-Rahim Kabupaten Deli Serdang Tahun 2021 didapat $\mathrm{L}_{\text {hitung }}=-0,0061$ dan $\mathrm{L}_{\text {tabel }}=0,258$ dengan $\mathrm{n}=10$ dan taraf $\alpha=0,05$, karena $\mathrm{L}_{\text {hitung }}<\mathrm{L}_{\text {tabel }}$ dapat disimpulkan bahwa sampel berasal dari populasi yang normal. Dari kolom daftar post-test latihan Plyometric Double Leg Speed Hop dan Single Leg Bounding terhadap Kecepatan Tendangan sabit pada Atlet Putra Perguruan Pencak Silat Al-Hikmah Ar-Rahim Kabupaten Deli Serdang Tahun 2021 didapat $\mathrm{L}_{\text {hitung }}=0,212$ dan $\mathrm{L}_{\text {tabel }}=0,258$ dengan $\mathrm{n}=10$ dan taraf $\alpha=0,05$, karena $\mathrm{L}_{\text {hitung }}<\mathrm{L}_{\text {tabel }}$ dapat disimpulkan bahwa sampel berasal dari populasi yang normal.

Pengujian Hipotesis dilakukan dengan uji- $t$ berpasangan untuk mengetahui pengaruh dari latihan Plyometric Double Leg Speed Hop dan Single Leg Bounding terhadap Kecepatan Tendangan sabit pada Atlet putra Perguruan Pencak Silat Al-Hikmah Ar-Rahim Kabupaten Deli Serdang Tahun 2021. Berdasarkan hasil perhitungan yang dilakukan maka diperoleh thitung sebesar 7,05. Selanjutnya nilai tersebut dibandingkan dengan nilai dengan $\mathrm{dk}=\mathrm{n}-1 \quad(10-1=9)$ pada taraf signifikan $\alpha=0,05$ adalah 1,833 , dengan demikian $t_{\text {hitung }}>t_{\text {tabel }}(7,05>1,833) \mathrm{H}_{0}$ ditolak dan $\mathrm{H}_{\mathrm{a}}$ diterima. 


\section{SIMPULAN}

Dari hasil pengujian hipotesis ditarik kesimpulan bahwa terdapat pengaruh yang signifikan dengan pemberian bentuk latihan plyometric double speed hop dan single leg bounding terhadap kecepatan tendangan sabit pada atlet putra perguruan al-hikmah ar-rahiim kabupaten deli serdang. Dari hasil analisis data juga dapat diketahui bahwa hasil pre-test masih rendah, maka dilakukan penerapan latihan Plyometric pada proses latihan atlet, latihan yang di gunakan peneliti adalah latihan Plyometric Double Leg Speed Hop dan Single Leg Bounding yang di modifikasi. Menurut peneliti dengan jenis latihan dan waktu penelitian memiliki pengaruh yang cukup besar untuk meningkatkan Kecepatan Tendangan Sabit.

\section{DAFTAR PUSTAKA}

Cania, O.P, Sugihartono, T \& Nopianto, Y.E (2021). Pengaruh Single Leg Bound Dan Split Jump Terhadap Kecepatan Tendangan Lurus Pada Siswa Putra Perguruan Pencak Silat Collage Bengkulu City. Volume. 2. No. 1 April 2021.

Harsono. (2018). Kepelatihan Olahraga. Bandung. PT. Remaja Rosdakarya.

Hidayad, M., \& Santoso, D.A. (2016). Pengaruh Latihan Plyometric Split Jumps dan Double Leg Speed Hop terhadap Kecepatan Tendangan Depan pada Siswa Putra Ekstrakurikuler Pencak Silat di Smp Negeri 2 Kalipuro Tahun Pelajaran 2015/2016. Jurnal Kejaora, Volume 1 Nomor 2, ISSN 2541-5042

Lubis, J., \& Wardoyo, H. (2016). Pencak Silat; Edisi kedua. Jakarta: PT Raja Grafindo Persada

Lubis, Johansyah. (2013). Panduan Praktis Penyusunan Program Latihan. Jakarta: Rajawali Pers.

Nurjaman, Z \& Rohmat, D. (2018). Perbandingan Metode Latihan Tcssm Dan Plyometric Terhadap Peningkatan Power Otot Tungkai Atlet Pencak Silat. Jurnal Kepelatihan Olahraga, volume 10, no. 1 juni 2018

Ogo, Andi. (2018). Hubungan power tungkai dan keseimbangan terhadap tendangan sabit pada ekstrakurikuler pencak silat di MI AT-TAUBAG kota Bekasi.jurnal genta mulia. Volume 9, no 2 juli 2018.

Rahman, Arif (2018). Pengaruh Latihan Double Leg Speed Hop Dan Hopscotch Terhadap Peningkatan Power Tungkai Pada Atlet UKM Pencak Silat PSHT Di Universitas Negeri Malang. Volume. 7. No.3 Agustus 2018.

Ramadhan, T \& Purnamasari (2020). Latihan Single Leg Speed Hop Dan Double Leg Speed Hop untuk Meningkatkan Power Tungkai dan Kecepatan Renang Gaya Dada. Volume, 12. No, 2. September 2020

Sudjana. (2005). Metode Statistika. Bandung: Tarsito

Syafruddin. (2011). Ilmu Kepelatihan Olahraga. Padang: UNP press

Widiastuti. (2011). Tes dan Pengukuran Olahraga, Jakarta: PT. Bumi Timur Jaya. 